\title{
Antibacterial activity of selected varieties of Malaysian honey against Escherichia coli: A comparative study
}

\author{
Mohammad A. Al-kafaween ${ }^{1}$ \\ Hamid A. Nagi Al-Jamal ${ }^{1}$, Abu Bakar Mohd Hilmi ${ }^{1}$ \\ 1 Faculty of Health Sciences, Universiti \\ Sultan Zainal Abidin, Terengganu, \\ Malaysia.
}

\section{Abstract}

Background: The purpose of this study was to investigate the antibacterial activity of three varieties of Malaysian honeybees; Tualang honey $(\mathrm{TH})$, Gelam honey $(\mathrm{GH})$, and Acacia honey $(\mathrm{AH})$ against Escherichia coli.

Methods: The minimum inhibitory concentration (MIC) and minimum bactericidal concentration (MBC) of the honey samples against $E$. coli were determined by the broth microdilution assay in the presence and absence of catalase enzyme. The mode of inhibition of honey samples against $E$. coli was investigated by the effect of time on viability. Impacts of the honey samples on the expression profiles of the selected genes of $E$. coli were examined using RT-qPCR analysis.

Results: The results showed that $\mathrm{TH}$ and $\mathrm{GH}$ honey possessed lowest MIC and MBC values against $E$. coli with $20 \%$ and $25 \%(\mathrm{w} / \mathrm{v})$ respectively. Highest MIC and MBC values were observed by $\mathrm{AH}$ honey against $E$. coli with $25 \%(\mathrm{w} / \mathrm{V})$ and $50 \%(\mathrm{w} / \mathrm{v})$ values, respectively. Among the tested honey samples, $\mathrm{TH}$ and $\mathrm{GH}$ exhibited the highest total antibacterial activity and the highest levels of peroxide-dependent activity. Time-kill curve demonstrated a bactericidal rather than a bacteriostatic effect; with a 2-log reduction estimated within 540 min. Viable cells were not recovered after 9 hours exposure to MIC of all honey-treated samples. The RT-qPCR analysis showed that all honey-treated cells share a similar overall pattern of gene expression, with a trend toward reduced expression of the virulence genes of interest.

\section{Contact information:}

Hamid A. Nagi Al-Jamal, Mohammad A. Al-kafaween. 
Conclusion: This study demonstrates that Malaysian honey have the potential to be effective inhibitor and virulence modulator of $E$. coli via multiple molecular targets.

\section{Keywords}

Antibacterial activity, Escherichia coli, Minimum inhibitory concentration, Minimum bactericidal concentration, Malaysian honey,

RT-qPCR Time-kill curve.
Received 20-02-2021; Accepted 17-03-2021

\section{Introduction}

Honeybees is one of the oldest traditional medicines that has been highly reputed and widely used for the treatment of several human diseases for thousands of years [1]. This reputation has continued up to the present day, leading to the emergence of a relatively new branch of alternative medicine, called "apitherapy", which focuses on medical applications of honey and other bee products [2-3]. Nowadays, different types of honey have been used in many countries as an alternative to pharmaceutical products for treating contaminated, infected, and burn wounds [4-5]. This is attributed to the effectiveness of these honeybees in inhibiting or killing a broad spectrum of bacteria [6-7]. E. coli is particularly interesting because it has been recognized as one of the most frequently isolated bacteria in nosocomial and surgical-site infections [8]. Although some studies have examined the effects of honeybees on bacterial structures $[9,10]$, the majority of these studies were conducted on one type of honey, known as Manuka honey, and were mostly focused on Pseudomonas aeruginosa and Staphylococcus aureus. The antimicrobial activity of honey may be attributed to several factors, including high osmolality, acidity, in addition to the presence of hydrogen peroxide $\left(\mathrm{H}_{2} \mathrm{O}_{2}\right)$ [11] and non-peroxide components, such as methylglyoxal [12]. In addi- tion to exerting direct antimicrobial effects, some honey varieties have been implicated in the differential expression of a number of genes essential for bacterial survival and virulence, including those involved in virulence factor production [13], stress tolerance [14], as well as multicellular behaviours, such as biofilm formation [15], and quorum sensing [16]. Honey's composition (and hence its antimicrobial activity) is dependent on the environmental and geographical locations from which the original nectar was collected [17]. This is attributed to natural variations in floral sources and climatic conditions at different locations [17]. Several studies have addressed different aspects of Malaysian honey varieties, including their physicochemical properties, their chemical composition, their antibacterial and antibiofilm activities and their therapeutic usefulness [18-20]. However, it is not yet known whether these anti-biofilm activities, as well as any possible anti-quorum sensing and anti-virulence activities possessed by these honeys could be attributed to alteration of bacterial gene expression. To the best of our knowledge, only three published studies to date have focused on the honey-induced expression patterns in E. coli [15-17, 21-22]. Therefore, the objectives of the present study were threefold: (a) to evaluate the direct antimicrobial activity of three varieties of the Malaysia honey against E. coli in vitro; (b) to 
estimate the impacts of these honey varieties on the expressions of virulence-related genes, with focus on genes involved in biofilm formation, quorum sensing, and stress survival.

\section{Materials and Methods}

\section{Honey sample}

Three Malaysian honey samples of different floral origins, namely, Tualang honey (TH), Gelam honey $(\mathrm{GH})$, and Acacia honey $(\mathrm{AH})$ were obtained from the apiarists and all honey samples were stored at $4^{\circ} \mathrm{C}$ in the dark until further analysis. The Three types of honey used were: (a) Tualang; a wild polyfloral honey produced by Apis dorsata located on one of the tallest tropical rainforest trees from species Koompassia excelsa. (b) Gelam; honey derived from mangrove swamp in Johore state known as Melaleuca cajuputi powell, and (c) Acacia; honey derived from a plant widely used in the forest plantation industry from Sarawak state of Malaysia known as tropical acacia species or Acacia mangium $[21,23]$.

\section{Free, lactonic, and total acidity of honey} Honey acidity was determined by a titrimetric method [24-25]. Briefly, $10 \mathrm{~g}$ of each honey samples were dissolved in $100 \mathrm{ml}$ of distilled water and the $\mathrm{pH}$ was assessed by means of a digital $\mathrm{pH}$ meter. The honey solutions were then titrated with $0.05 \mathrm{~N}$ Sodium hydroxide $(\mathrm{NaOH})$ solution until $\mathrm{pH}$ 8.5 was achieved (to determine the free acidity). This was followed by an immediate back titration with $0.05 \mathrm{~N}$ Hydrochloric acid $(\mathrm{HCl})$ until the $\mathrm{pH}$ reached 8.3 (to determine the lactonic acidity). Total acidity was obtained by adding free and lactonic acidities. Results were expressed as mille-equivalent of acid per kilogram (meq $\mathrm{kg}^{-1}$ ) of honey. The procedure was repeated three times in order to achieve accurate result.
Total and non-peroxide antibacterial activity of honey

Honey samples were tested for antimicrobial activity against E. coli ATCC 25922 as the bacterial model strain, obtained from the American Type Culture Collection. Using sterile 96-well plates, the minimum inhibitory concentrations (MICs) were determined by the broth microdilution assay, as described by [26] with minor modifications. All honey solutions were freshly prepared before each assay. All assays were performed in triplicate samples and were repeated three times to obtain reliable results. To determine the total (peroxide and non-peroxide) antibacterial activity, a series of concentrations of each type of honey was prepared in Nutrient broth (Oxoid, England) to obtain concentrations of $75 \%, 50 \%, 25 \%, 12.5 \%$, $6.25 \%, 3.125 \%$ and $1.56 \%$. In addition, $20 \%$ (w/v) was prepared. These honey solutions were filtered through $0.45 \mu \mathrm{m}$ filters and $150 \mu$ of the filtrate was placed in each of the test wells of 96-well plates. The working bacterial culture was prepared by adjusting an overnight culture of the test organism to be $0.5 \mathrm{McFarland}$ standard and further diluting it in NB to yield a working bacterial suspension of approximately $5 \times 10^{6} \mathrm{CFU} / \mathrm{ml}$. The 96-well plates were then inoculated with $50 \mu \mathrm{l}$ of the working bacterial suspension to achieve a final test concentration of bacteria of approximately 5 $x 10^{8} \mathrm{CFU} / \mathrm{ml}$ in each well. The plates were incubated at $37^{\circ} \mathrm{C}$ for 24 hours in a shaker incubator (100 rpm). Positive (growth) controls (consisting of inoculated broth), and negative (sterility) controls (containing uninoculated broth and honey) were included. Wells with the lowest concentration of honey that showed no visible growth were regarded as the MIC $[8,18]$. In addition to their visual determination, MICs were confirmed by measuring the absorbance at $570 \mathrm{~nm}$ using a plate reader (Tecan Infinite 200 PRO, Austria). The non-peroxide antibacterial activity of the honey samples was evaluated as described above, with the exception 
that catalase (Sigma; at a final concentration of $1 \%$ $w / v$ ) was added to each honey dilution to remove its content of $\mathrm{H}_{2} \mathrm{O}_{2}$. Positive (growth) control wells (consisting of inoculated broth and catalase), and negative (sterility) control wells (containing uninoculated broth, the corresponding honey, and catalase) were processed along with each honey sample subjected to the assay [8].

The minimum bactericidal concentration (MBC) was determined by taking a loopful of the culture medium from each test well (from the broth MIC assay) that showed no apparent growth and subculturing on fresh nutrient agar (NA) plates. After incubation at $37^{\circ} \mathrm{C}$ for 24 hours, the $\mathrm{MBC}$ was read as the least concentration showing no growth on the NA plates $[23,27]$.

\section{Time-kill curve}

The minimum inhibitory concentration of $\mathrm{TH}, \mathrm{GH}$ and $\mathrm{AH}$ that was chosen for subsequent experiments. Working bacteria culture was adjusted to be $\left.1 \times 10^{5} \mathrm{cfu} / \mathrm{ml}\right)$.

The effect of $\mathrm{TH}, \mathrm{GH}$ and $\mathrm{AH}$ on the viability of cells was monitored by inoculating $40 \mu \mathrm{L}$ of an overnight culture of $E$. coli into $20 \mathrm{~mL} \mathrm{NB}$ with and without $\mathrm{TH}, \mathrm{GH}$ and $\mathrm{AH}$ and incubated at $37^{\circ} \mathrm{C}$ in a shaking water bath (100 rpm). Samples were removed at known intervals and the TVCs determined as above $[23,27]$.

\section{Reversibility of inhibitory effects}

Working bacteria culture was prepared as previously described, adjusted to be equal to $1 \times 10^{5}$ $\mathrm{cfu} / \mathrm{ml})$. Cultures of $E$. coli with and without MIC $\mathrm{TH}, \mathrm{GH}$ and $\mathrm{AH}$ in NB were set up as in the timekill studies and incubated at $37^{\circ} \mathrm{C}$ in a shaking water bath. At time 0 and at hourly intervals, $100 \mu \mathrm{L}$ samples were removed from each of the flasks, transferred to $10 \mathrm{~mL} \mathrm{NB}$, incubated overnight at $37^{\circ} \mathrm{C}$ and the viability deduced by the presence of turbidity [28].

\section{RNA isolation and CDNA synthesis}

A volume of $20 \mathrm{ml}$ of each of the tested honeys was prepared at inhibitory concentrations (MIC) in NB broth medium and filter sterilized. An overnight culture of $E$. coli was diluted 1:100 and cells were grown in NB broth to mid-exponential phase $\left(O D_{600}=0.3-0.5\right)$. Aliquots of this culture $(500 \mu l)$ were used to inoculate the honey solutions, which were then incubated with shaking at $37^{\circ} \mathrm{C}$ for 9 h. At the end of incubation, samples were washed twice with cold phosphate-buffered saline. The supernatant was discarded and the pellet was washed with PBS. The pelleted cells were resuspended in $50 \mu \mathrm{l}$ of lysozyme (Sigma-Aldrich, UK), and 50 $\mathrm{\mu l}$ mutanolysin (Sigma-Aldrich, UK) and incubated at room temperature for 10 minutes and total RNA was isolated using kit SV Total RNA Isolation System (Promega, UK) according to the recommendations of the manufacturer. The concentration and purity of the isolated total RNA was determined by the ND-1000 spectrophotometer (NanoDrop, USA), and the integrity of the RNA samples was verified by agarose gel electrophoresis. Finally, $1 \mu \mathrm{g}$ of total RNA from each sample was reverse-transcribed to cDNA using cDNA Synthesis Kit (Promega, UK). For each reaction, qPCR mastermix was prepared by following the manufacturer's instructions (Promega, UK) as per the manufacturer's instructions. In parallel, RNA was isolated from both untreated bacterial cells and $\mathrm{TH}, \mathrm{GH}$ and $\mathrm{AH}$ honey-treated ones, and subjected to cDNA synthesis, using the same procedures $[8,23]$.

\section{Quantitative real-time polymerase chain reac- tion (RT-qPCR) analysis}

The effects of honeys on the expression levels of eight target genes [yjfO (bsmA), csgA, ycfR (BhsA), tnaA, IsrA, evgA, rpoS, and $H$-NS] involved in biofilm formation, quorum sensing, and stress survival in the tested organism, were examined using qPCR. Primers for the GPCR used in the current study were selected from previous studies as shown in Table 1. 
Table 1. Gene specific primers of $E$. coli used for RT-qPCR analysis [21, 30].

\begin{tabular}{|c|c|c|c|c|}
\hline \multirow{2}{*}{ Gene name* } & $\begin{array}{l}\text { Amplicon } \\
\text { Size }\end{array}$ & $\begin{array}{l}\text { Annealing } \\
\text { temnerature }\end{array}$ & \multirow{2}{*}{ Direction } & Primer sequence \\
\hline & bp & ${ }^{\circ} \mathrm{C}$ & & $5^{\prime} \rightarrow 3^{\prime}$ \\
\hline yjfO (bsmA) & 76 & 53 & $\begin{array}{l}\text { Forward } \\
\text { Reverse }\end{array}$ & $\begin{array}{l}\text { CGCCAGTAACGGACCATC } \\
\text { GTGCTTACGCTACCTATTCG }\end{array}$ \\
\hline $\operatorname{csg} A$ & 191 & 56 & $\begin{array}{l}\text { Forward } \\
\text { Reverse }\end{array}$ & $\begin{array}{l}\text { ATGGCGGCGGTAATGGTG } \\
\text { GTTGACGGAGGAGTTAGATGC }\end{array}$ \\
\hline$y c f R$ (BhsA) & 81 & 54 & $\begin{array}{l}\text { Forward } \\
\text { Reverse }\end{array}$ & $\begin{array}{l}\text { CGAAGTTCAGTCAACGCCAGAAG } \\
\text { TCCAGCGATCCCAGATTTGTCC }\end{array}$ \\
\hline $\operatorname{tna} A$ & 174 & 54 & $\begin{array}{l}\text { Forward } \\
\text { Reverse }\end{array}$ & $\begin{array}{l}\text { CTGGATAGCGAAGATGTG } \\
\text { CGGAATGGTGTATTGATAAC }\end{array}$ \\
\hline IsrA & 178 & 55 & $\begin{array}{l}\text { Forward } \\
\text { Reverse }\end{array}$ & $\begin{array}{l}\text { TACTCATAACCTTCGTGGATTCTG } \\
\text { TACTTGCGGCGAGGCTTC }\end{array}$ \\
\hline evgA & 155 & 53 & $\begin{array}{l}\text { Forward } \\
\text { Reverse }\end{array}$ & $\begin{array}{l}\text { TAGCGGAGACGATAATAATAATTC } \\
\text { GTTGACTGAAGGCGGAAG }\end{array}$ \\
\hline rpos & 199 & 54 & $\begin{array}{l}\text { Forward } \\
\text { Reverse }\end{array}$ & $\begin{array}{l}\text { CTCAACATACGCAACCTG } \\
\text { GTCATCAACTGGCTTATCC }\end{array}$ \\
\hline$H-N S$ & 170 & 54 & $\begin{array}{l}\text { Forward } \\
\text { Reverse }\end{array}$ & $\begin{array}{l}\text { CCGAACGAACTGCTGAATAG } \\
\text { TTACCTTGCTCATCCATTGC }\end{array}$ \\
\hline ftsA & 152 & 55 & $\begin{array}{l}\text { Forward } \\
\text { Reverse }\end{array}$ & $\begin{array}{c}\text { GAAGAAGTGACGCAAGAAGATG } \\
\text { ACGCCCGAAAGTCCTACC }\end{array}$ \\
\hline $16 S$ rRNA & 189 & 55 & $\begin{array}{l}\text { Forward } \\
\text { Reverse }\end{array}$ & $\begin{array}{c}\text { CACACTGGAACTGAGACAC } \\
\text { CTTCTTCTGCGGGTAACG }\end{array}$ \\
\hline
\end{tabular}

The GPCR mastermix for each reaction was prepared based on the manufacturer's instructions (Promega, UK). All reactions $(20 \mu \mathrm{l})$ were performed using three technical replicates, with $100 \mathrm{ng}$ CDNA and $400 \mathrm{nM}$ primers per reaction. The PCR cycling conditions were as follows: one cycle with $95^{\circ} \mathrm{C}$ for 5 min (hot start); then 40 cycles of denaturation at $95^{\circ} \mathrm{C}$ for $30 \mathrm{~s}$, annealing and fluorescent data collection at $53-56^{\circ} \mathrm{C}$ (depending on primers used) for 30s, and extension at $72^{\circ} \mathrm{C}$ for $30 \mathrm{~s}$. On completion of the reaction, a dissociation curve was generated to verify that a single product was amplified. In all QPCR runs, negative controls (lacking the template or the reverse transcription step) were run in paraIlel. The 165 rRNA and the ftSA genes were selected as internal controls, and the stability of their expression among honey samples was assessed using the Best Keeper tool [29]. The relative mRNA levels of genes of interest were determined and normalized to the expression of the housekeeping genes using the Applied Biosystems StepOne Software v2.3. The qPCR data were expressed as the changes in expression levels of genes in honey-treated $E$. coli as compared to their levels in the untreated bacteria $[8,18]$. Experiments were run with three technical replicates of each. (Table 1)

\section{Statistical analysis}

All data obtained including quantitative QPCR were presented as mean values \pm standard deviation (SD). To determine significant differences between control and treated samples, independent student t-test from (SPSS version 20) was used. A difference with a $P$ value of $<0.05$ was considered to be statistically significant. 
Vol. 11 No. 1:3 doi: $10.3823 / 854$

\section{Results}

\section{Acidity of honey}

Among the analyzed honey varieties, TH showed the highest total acidity $(30.9 \pm 0.59 \mathrm{meq} / \mathrm{kg})$, followed by GH $(26.8 \pm 0.79 \mathrm{meq} / \mathrm{kg})$, and $\mathrm{AH}(24.95$ $\pm 0.82 \mathrm{meq} / \mathrm{kg}$ ). The $\mathrm{pH}$ values of the honeys ranged from 3.45 to 4.00 , which increased in the following order: $\mathrm{AH}(\mathrm{pH} 3.45)<\mathrm{GH}(\mathrm{pH} 3.64)<\mathrm{TH}$ (pH 4.00) (Table 2). Interestingly, when the lactonic acidity was calculated, the three honeys showed comparable levels of this acidity, in the range of 9-11 $\mathrm{meq} / \mathrm{kg}$.

Table 2. Acidity of the $\mathrm{TH}, \mathrm{GH}$ and $\mathrm{AH}$ (expressed as the mean of triplicate samples \pm standard deviation).

\begin{tabular}{l|c|c|c|c|}
$\begin{array}{c}\text { Honey } \\
\text { samples }\end{array}$ & pH & $\begin{array}{c}\text { Free } \\
\text { acidity } \\
\text { meq/kg }\end{array}$ & $\begin{array}{c}\text { Lactonic } \\
\text { acidity } \\
\text { meq/kg }\end{array}$ & $\begin{array}{c}\text { Total } \\
\text { acidity } \\
\text { meq } / \mathrm{kg}\end{array}$ \\
\hline TH & $4.00 \pm 0.02$ & $15.9 \pm 0.23$ & $11 \pm 0.34$ & $30.9 \pm 0.59$ \\
GH & $3.64 \pm 0.03$ & $13.2 \pm 0.31$ & $10 \pm 0.45$ & $26.8 \pm 0.79$ \\
\hline AH & $3.45 \pm 0.02$ & $12.5 \pm 0.26$ & $9 \pm 0.53$ & $24.95 \pm 0.82$
\end{tabular}

\section{Antibacterial activities}

The MIC values of the three tested Malaysian honeys against $E$. coli are shown in Table 3. TH and $\mathrm{GH}$ were recorded as the most potent honey against the test organism, which both showed MIC value of $20 \%(\mathrm{w} / \mathrm{v})$ was required to inhibit the bacterial growth. In the case of $\mathrm{AH}$, a concentration of $25 \%$ $(\mathrm{w} / \mathrm{v})$ was the lowest concentration required to inhibit the growth of the tested organism. To examine the influence of $\mathrm{H}_{2} \mathrm{O}_{2}$ on the antibacterial activity of the tested honeys, samples were pre-treated with catalase prior to the incubation with $E$. coli, which was followed by evaluation of their MIC values. The removal of $\mathrm{H}_{2} \mathrm{O}_{2}$ from the three tested honeys reduced their antibacterial activity against $E$. coli with different degrees. The highest reduction in antibacterial activity was observed in the case of $\mathrm{AH}$ honey, in which the removal of $\mathrm{H}_{2} \mathrm{O}_{2}$ caused an approxi- mate three-fold increase in the MIC against $E$. coli (from 25 to $75 \% \mathrm{w} / \mathrm{V}$ ) (Table 3). The results showed that both $\mathrm{TH}$ and $\mathrm{GH}$ honey possessed lowest MBC value against $E$. coli with $25 \%(\mathrm{w} / \mathrm{v})$. Highest MBC value was shown by $\mathrm{AH}$ honey against $E$. coli with $50 \%(\mathrm{w} / \mathrm{v})$. The close proximity of the MIC and MBC values (Table 3 ) indicated a bactericidal mode of action for $\mathrm{TH}, \mathrm{GH}$, and $\mathrm{AH}$ with $E$. coli.

Table 3. MICs of $\mathrm{TH}, \mathrm{GH}$, and $\mathrm{AH}$ on $E$. coli were assessed by the broth microdilution assay in the presence and absence of catalase enzyme.

\begin{tabular}{|l|c|c|c|}
\hline $\begin{array}{c}\text { Honey } \\
\text { samples }\end{array}$ & $\begin{array}{c}\text { Absence of } \\
\text { catalase } \\
\text { MIC \% }\end{array}$ & $\begin{array}{c}\text { Presence of } \\
\text { catalase } \\
\text { MIC \% }\end{array}$ & MBC \% \\
\cline { 2 - 4 } & W/V & W/V & W/V \\
\hline $\mathrm{GH}$ & 20 & 50 & 25 \\
$\mathrm{AH}$ & 20 & 50 & 25 \\
\hline $\mathrm{AH}$ & 25 & 75 & 50 \\
\hline
\end{tabular}

\section{Time-kill studies}

The time-kill curve clearly shows an increase in number of $E$. coli cells without $\mathrm{TH}, \mathrm{GH}$ and $\mathrm{AH}$ treatment (Figure 1). From figures bellow, TH was more effective for $E$. coli tested up to 8 hours than $\mathrm{GH}$ and $\mathrm{AH}$. However, $\mathrm{TH}, \mathrm{GH}, \mathrm{AH}$ honey resulted in 2.2-log, 1.9-log, and 1.6-log reduction in $\mathrm{cfu} / \mathrm{ml}$ of $E$. coli cells respectively compared to the starting inoculum at 9 hours incubation (Figure 1). Loss of viability was observed when bacteria were incubated with MIC $(\mathrm{w} / \mathrm{v}) \mathrm{TH}, \mathrm{GH}$ and $\mathrm{AH}$ in NB with time compared to untreated cells (Figure 1). Extrapolation of viable bacterial population sizes in the presence of $\mathrm{TH}, \mathrm{GH}$ and $\mathrm{AH}$ estimated that the mean time to achieve a 2-log reduction was 540 min.

\section{Reversibility of inhibitory effects}

Removing samples from cultures incubated with MIC TH, GH and AH in NB to NB alone demonstrated that viable cells were not recovered after 9 hours (Figure 2). This suggested that the inhibitory 
Vol. 11 No. 1:3

doi: $10.3823 / 854$
Figure 1: The effects of $\mathrm{TH}, \mathrm{GH}$, and $\mathrm{AH}$ on the viability of $E$. coli.

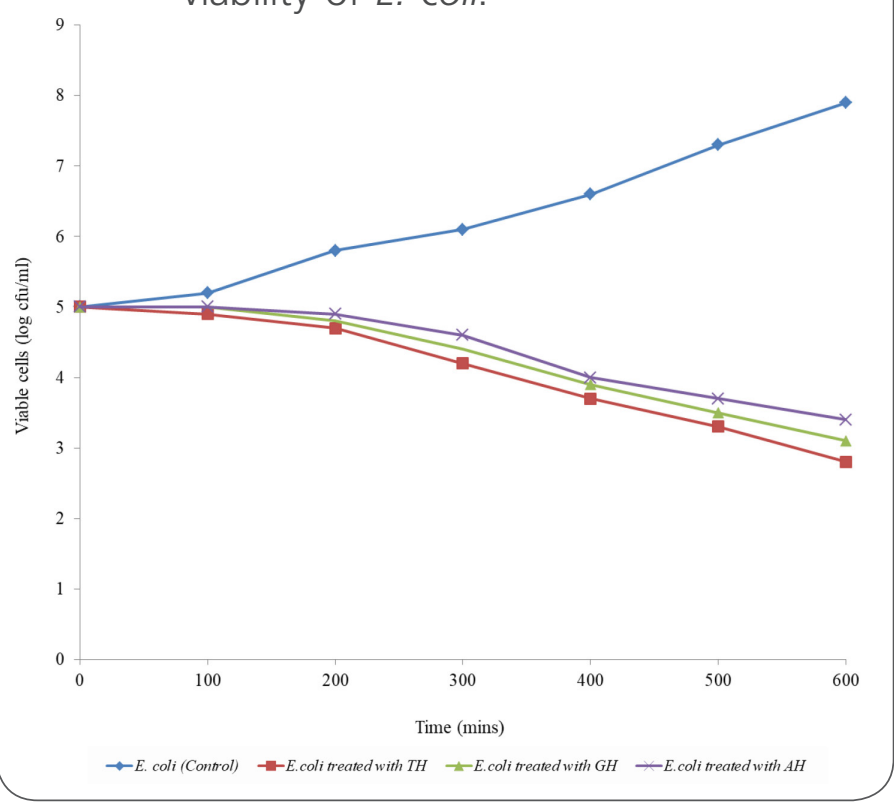

effect of $\mathrm{TH}, \mathrm{GH}$ and $\mathrm{AH}$ was irreversible. The MIC and $\mathrm{MBC}$ were confirmed by growth kinetics curve and time-kill studies, where cells exposed to $\mathrm{TH}, \mathrm{GH}$ and $\mathrm{AH}$ were found to lose viability with time, yet the numbers of untreated cells increased (Figure 2).

Figure 2: Growth analysis of $E$. coli treated with and without $\mathrm{MIC} \mathrm{TH}, \mathrm{GH}$ and $\mathrm{AH}$.

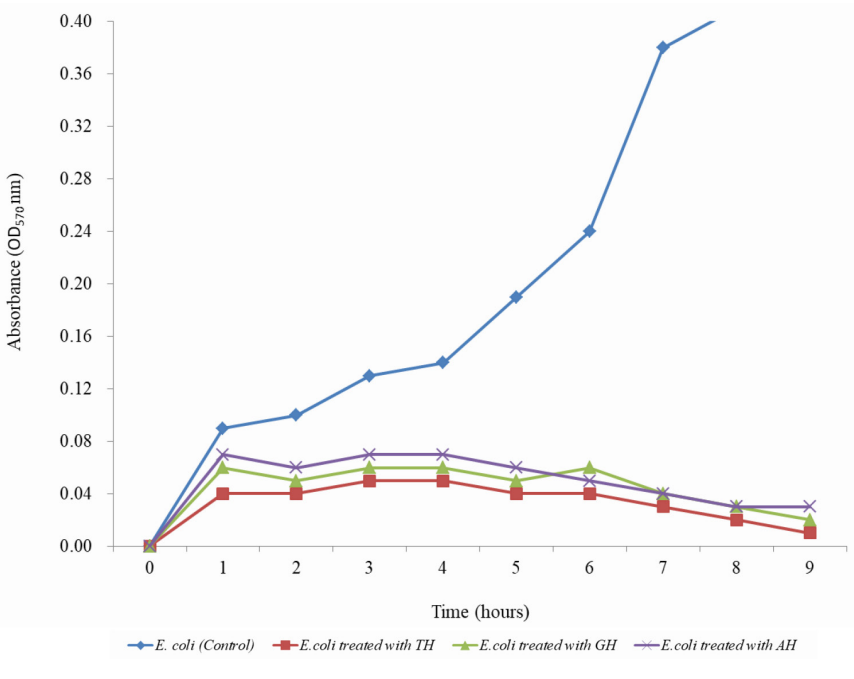

\section{RT-qPCR analyses}

In the current study, qPCR was used to evaluate and compare the impacts of exposure of $E$. coli cells to three Malaysian honeys (at MIC; for 9 h) on the ex- pression of eight genes that have been previously shown to be involved in the fitness and virulence of the microorganism. In this study, MIC (TH; MIC 20\% $\%(\mathrm{w} / \mathrm{v}), \mathrm{GH} ; 20 \%$ (w/v) and AH; MIC 25\% (w/v) was used for gene expression. Because MIC is defined as the lowest concentration of honey that prevents at least $99 \%$ of bacterial growth. The selected genes included three genes involved in biofilm formation [yjfO (bsmA), csgA, and ycfR (BhsA)], two genes involved in quorum sensing (tnaA and $/ s r A$ ), and three genes associated with stress survival (evgA, rpoS, and $H-N S)$. Ct values between biological replicas were standardized against the reference gene and changes in relative expression to untreated cells were analysed. As revealed by the independent student t-test from (SPSS version 20), there was a significant overall difference $(P<0.05)$ in the expression of each of the tested genes among the different groups. The $P$ values for each individual were as follows: yjfO (bsmA) $(P=0.0006) ; \operatorname{csgA}(P=0.0003) ; y c f R$ (BhsA $(P=$ $0.0015)$; thaA $(P<0.01)$; IsrA $(P<0.01)$; evgA $(P<$ $0.05) ; \operatorname{rpoS}(P<0.05)$; and $H$-NS $(P<0.05)$. These results were included in Figure 3 . All genes, with the exception of only two genes [ycfR (BhsA) and evgA] were downregulated following exposure to $\mathrm{TH}, \mathrm{GH}$ and $\mathrm{AH}$ under study (Figure 3). Although different degrees of downregulation were observed following exposure to the $\mathrm{TH}, \mathrm{GH}$ and $\mathrm{AH}$, all the downregulated genes showed less than six-fold change, except for the tnaA gene that was downregulated in the range of 11.3-14.4 fold (Figure 3). In the case of $y c f R$ (BhsA) and evgA genes, its expression was upregulated following exposure to the three tested Malaysian honeys. The fold increase in expression of the $y c f R$ (BhsA) gene was in the range of 2.9-7.2 fold, while evgA was upregulated in the range of 0.54-0.78 fold following exposure to Malaysian honeys (Figure 3). In the case of $\mathrm{H}$-NS gene, its expression was downregulated following exposure to $\mathrm{TH}$ and $\mathrm{GH}$, while remained unaltered after exposure to $\mathrm{AH}$ (Figure 3 ). The fold decrease in expression of the H-NS gene was in the range of 1.12-1.31 fold. 
Figure 3: Alterations in gene expression profiles associated with exposure of $E$. coli to the $\mathrm{TH}, \mathrm{GH}$, and $\mathrm{AH}$ as determined by qPCR.

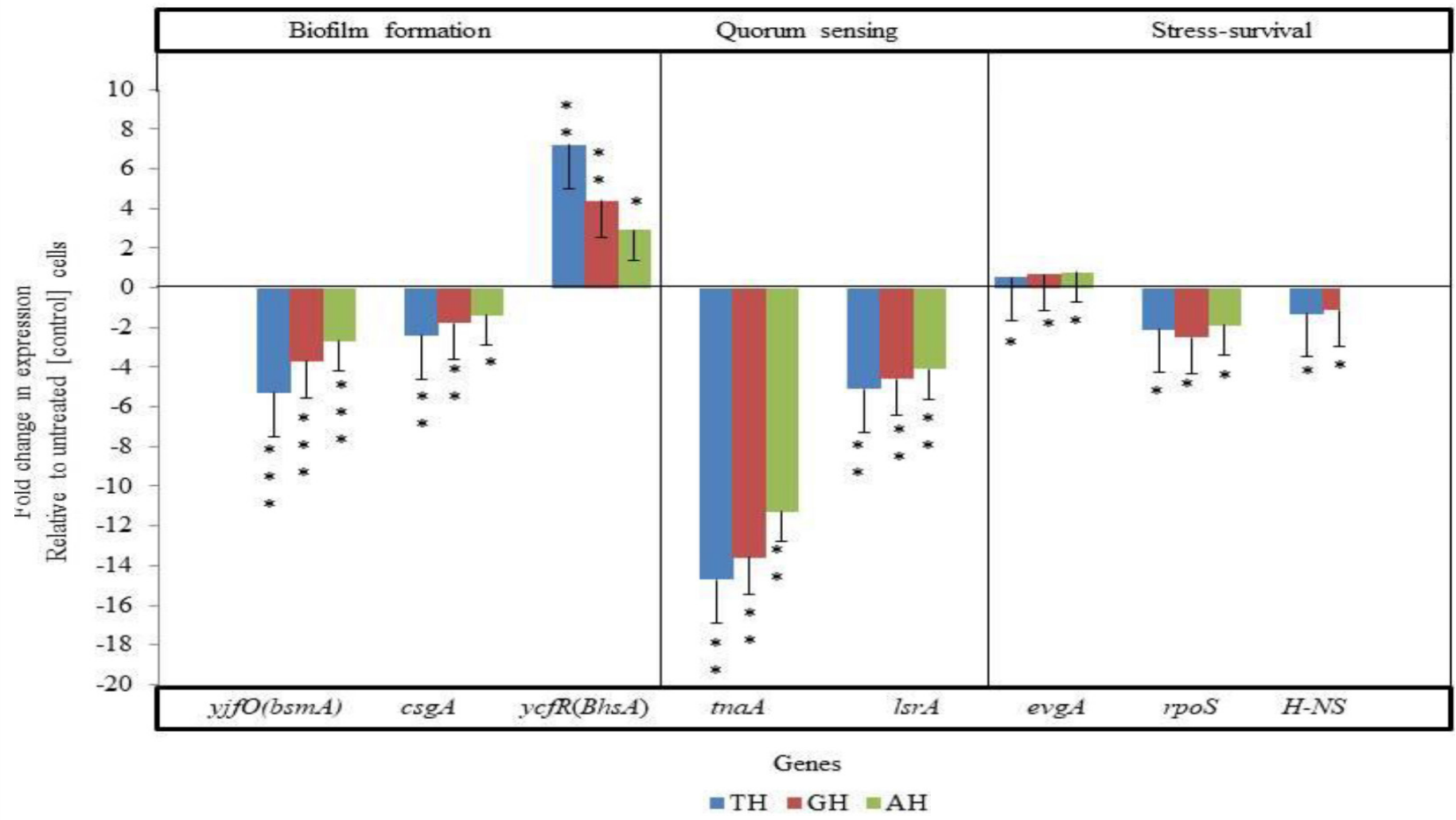

Mean values of fold changes $( \pm S D$ ) are shown in relation to untreated (control) E. coli cells. Asterisks indicate statistically significant differences in the expression of each gene between treated samples and control ( $\left.{ }^{*} \mathrm{P}<0.05 ;{ }^{* *} \mathrm{P}<0.01 ;{ }^{* * *} \mathrm{P}<0.001\right)$.

To evaluate the contribution of osmolarity and acidity on the level of expression of the target genes, this assay was also performed on cDNA synthesized from RNA extracted following exposure of the cells to an $\mathrm{TH}, \mathrm{GH}$ and $\mathrm{AH}$ solution. In the presence of honeys, downregulation in the expression of all the tested quorum-sensing genes, and upregulation in the expression of evgA involved in stress survival was observed with E. coli (Figure 3). In the case of biofilm-forming genes, exposure of $E$. coli cells to Malaysian honeys caused a decreased expression of yjfO (bsmA) and csgA, while it caused an increased expression of ycfR (BhsA) (Figure 3).

\section{Discussion}

The ability of different types of honey to combat infections may be attributed to at least two complementary mechanisms. The first mechanism is attributed to their direct biocidal activity, owing to the presence of multiple factors that can damage susceptible organisms [16]. The second mechanism is mediated through their anti-virulence activity, by down regulating the expression of genes associated with virulence factor production, stress tolerance, and/or multicellular behaviours of the target organism (such as biofilm formation and quorum sensing) [16]. This latter mechanism will eventually weaken bacterial coordination, decrease their survival abilities, and interfere with their virulence mechanisms. It is well known that the total antibacterial activity of honey is attributed to multiple factors, including its high osmolarity, acidity, in addition to its content of hydrogen peroxide $\left(\mathrm{H}_{2} \mathrm{O}_{2}\right)$ and non-peroxide phytochemical components [31]. Therefore, the current stu- 
dy assessed these individual antibacterial factors and evaluated their relative contributions to the overall antibacterial activities of the honeys under study. The antibacterial activity of honey has been assayed using various methods across the globe with special attention devoted to minimum inhibitory concentration (MIC) and minimum bactericidal concentration (MBC). In this study, MIC was performed using 96-well microtitre plate and data were collected by means of a spectrophotometric endpoints evaluation. MIC is defined as the lowest concentration of honey that prevents at least $99 \%$ of bacterial growth while $\mathrm{MBC}$ is defined as the lowest concentration of honey required to kill at least $99 \%$ of the bacteria [27]. To examine the effect of peroxide, the MIC values were determined in the presence and absence of catalase enzyme, which is known to break down $\mathrm{H}_{2} \mathrm{O}_{2}$. The possible contribution of $\mathrm{pH}$ and acidities (free, lactonic and total) in solutions of the tested honeys were investigated. In the absence of catalase, the MIC values of the $\mathrm{TH}$ and $\mathrm{GH}$ were 1.2 fold lower than that observed with the $\mathrm{AH}$ was 2 fold. This may indicate that the phytochemical components exerted a more specific growth-inhibitory activity against $E$. coli than the osmotic effects of sugars. In this respect, several reports have shown the high antimicrobial activity of Trigona, Tualang, Gelam and Acacia honeys against both Gram-positive and Gram-negative bacterial strains [27, 32, 33]. Previous findings by Tan et al., (2009) reported that honey tualang was superior in their antimicrobial activity against E. coli [34]. Our findings support and confirm those mentioned earlier, since among the honeys investigated, that $\mathrm{TH}$ and $\mathrm{GH}$ exhibited the highest total antibacterial activity against $E$. coli, as indicated by having the lowest MIC values in the absence of catalase $(20 \% \mathrm{w} / \mathrm{v})$. These types of honeys also showed the highest levels of hydrogen peroxide dependent activity, as the removal of its $\mathrm{H}_{2} \mathrm{O}_{2}$ (by catalase enzyme) caused the highest fold increase in $\mathrm{MIC}$, resulting in an approximately three fold-shift. In the current study, both $\mathrm{TH}$ and $\mathrm{GH}$ honey varietes showed equal MIC values of $20 \%(\mathrm{w} / \mathrm{v})$ and $\mathrm{AH}$ honey MIC value $25 \%(\mathrm{w} / \mathrm{v})$. These MICs were comparable, to some extent, with those obtained by Zainol et al., (2013), who reported antibacterial activities of Malaysian Tualang, Gelam and Acacia honeys against E. coli, with the MIC values of $20 \%, 12.5 \%$, and $25 \%$ (w/v) respectively [27]. However, in agreement to our results previous study reported that Tualang honey possessed higher antimicrobial activity against $E$. coli with the MIC value of $22.5 \%(\mathrm{w} / \mathrm{v})$ [34]. These similarity and conflicting results may be attributed to the differences in geographical and seasonal sources, as well as harvesting, processing, and storage conditions of the honeys tested. Reductions in viable cells seen in the time-kill experiments (Figure 1) confirmed a bactericidal mode of action, with a time to achieve 2-log reductions estimated to be $540 \mathrm{~min}$. Failure to recover viable bacteria after 9 hours in the reversibility experiment confirmed that the inhibition was irreversible (Figure 2). Turning to evaluation of acidity, the three tested honeys were acidic in nature, with $\mathrm{pH}$ values ranging from 3.45 to 4.00 , which are likely to be low enough to inhibit the growth of many microorganisms [31]. The obtained values were in line with those of previous studies that reported a $\mathrm{pH}$ ranging from 3.8 to 5.2 among different Malaysian Tualang, Gelam and Acacia honey varieties $[20,35,36]$. Interestingly, although the total and free acidity values in $\mathrm{AH}$ honey were both less than the corresponding values of $\mathrm{TH}$ and $\mathrm{GH}$ honeys, the antibacterial activity of the $\mathrm{TH}$ and $\mathrm{GH}$ honeys was higher than the $\mathrm{AH}$ honey. This observation is consistent with that of Badawy et al., (2004), who found no correlation between free acidity of honey and its antibacterial activity against tested E. coli [37]. The findings suggest that each honey has different effects on the tested bacteria. This could be due to the presence of different organic antibacterial factors contributed by honey [38, 39]. 
A number of genes have been shown to be involved in the fitness and virulence of $E$. coli, and thus modulating the expression of these genes can add to the effectiveness of antimicrobial therapy. Herein, eight of these genes playing important roles in biofilm formation, quorum sensing, and stress survival in $E$. coli were selected, and their differential gene expression profiles in response to exposure to the tested honeys were determined using $\mathrm{qPCR}$.

A number of genes [including yjfO (bsmA), csgA, and $y c f R(B h s A)]$ have been previously shown to be involved in the process of biofilm formation in $E$. coli [40-42]. The current results showed that both yjfO (bsmA) and $\operatorname{csg} A$ were downregulated after honey treatment, while ycfR (BhsA) was upregulated. This pattern of expression was the same regardless of the tested honey. The importance of this expression pattern becomes clearer when it is taken into account that yjfO (bsmA) and $\operatorname{csg} A$ have been previously characterized as biofilm-promoting genes in E. coli $[40,41]$, while ycfR (BhsA) has been shown to act as a biofilm repressor gene [42]. Therefore, the current findings may suggest that the honeys under study can prevent or disrupt E. coli biofilms. In a study conducted by Weber et al., (2010) mutation of the yjfO gene in $E$. coli has been shown to cause alteration of cell motility, increased sensitivity to $\mathrm{pH}$ and oxidative stresses, and reduction of viability, rather than only affecting the biofilm formation [41].

A set of genes have been previously shown to play an important role in the quorum-sensing network of $E$. coli, such as the tnaA and IsrA genes [43]. The present results showed that both genes were down regulated in response to all the tested honeys. It is tempting to speculate that the tested honeys may act as quorum-sensing inhibitors, and thus may have the potential to decrease the virulence of pathogens like $E$. coli, by interrupting their cellular communication system. The current results are in agreement with those of Lee et al., (2011), who reported down regulation of multiple genes involved in biofilm formation and quorum sensing in the pathogenic $E$. coli strain following exposure to honey samples from Korean and American origins [44].

Since bacterial cells are exposed to various stressful conditions, these cells are equipped with stress survival mechanisms, being encoded in $E$. coli by a number of genes, including the evgA, rpoS, and H-NS [45-47]. Among these three tested genes, rpoS and $H$-NS were downregulated after exposure to $\mathrm{TH}$ and $\mathrm{GH}$ while remained unaltered after exposure to $\mathrm{AH}$. The expression profile of evgA was upregulated and has approximately similar pattern in expression after exposure to all the tested honeys. Given the various stresses caused by honey exposure (including acid, osmotic, and oxidative stresses triggered by $\mathrm{H}_{2} \mathrm{O} 2$ ), it is likely that the downregulation of the above-mentioned genes will render bacterial cells less protected against stresses and damage caused by honey, which may eventually lead to loss of viability once the damage is beyond repair (Figure 4).

The current results are in agreement with those of Wasfilet al., (2016), who reported downregulation of rpoS, $\mathrm{H}$-NS, and evgA genes following treatment of $E$. coli to Egyptian honeys [8]. Also, our results are in contrast to those of Blair et al. [22], who showed marked upregulation in rpoS, H-NS, and evgA genes following exposure of $E$. coli to Manuka honey. This difference in expression pattern may reflect differences in the phytochemical constituents and/or differences in the antimicrobial mechanisms of the tested honeys in both studies [31],

Contrary to the effect of most of the tested honeys, exposure of $E$. coli to Malaysian honey varieties resulted in downregulation of all the tested stress survival genes (rpoS and $H$-NS) except evgA (Figure 3). This indicates that the honey-induced changes in expression of this group of genes are most probably due to specific molecules contained in these honeys and not simply due to their sugar content. This suggests that the antiquorum sensing activities 
Figure 4: Schematic diagram summarizing the effects of the tested honeys on E. coli ATCC 8739 at both structural and molecular levels.

\section{Escherichia coli (ATCC 25922)}

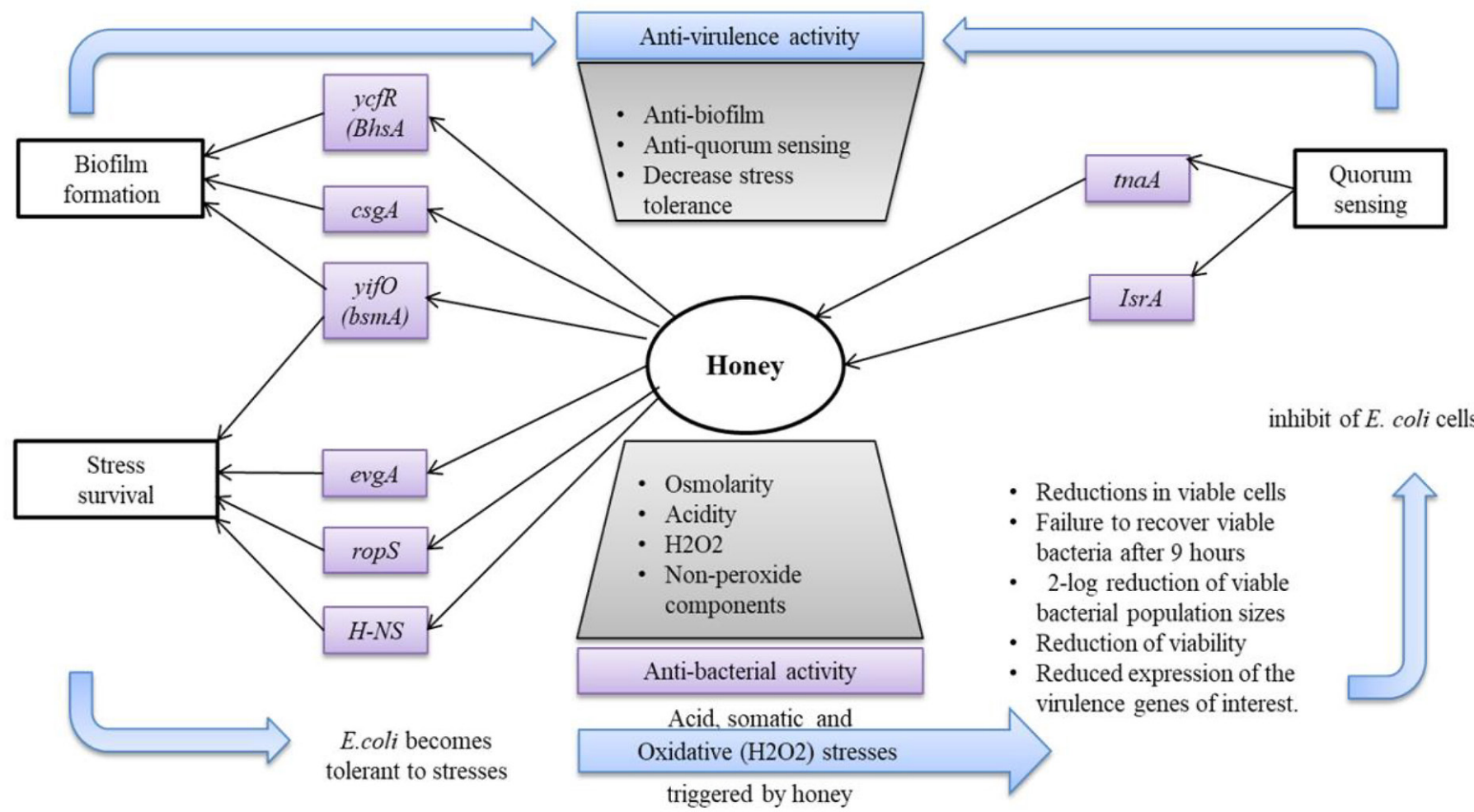

In this figure, thin lines with pointed arrows indicate induction of gene expression or stimulation of a phenotype, while bar-headed lines indicate repression of gene expression or repression of a phenotype. Adapted from Wasfi et al., (2016) with a modification according to our study.

of the tested honeys are, at least partially, attributed to their sugar content, which is in accordance to the results of a previous study $[8,16]$.

\section{Conclusion}

The results of this study demonstrated that the tested Malaysian honeys have the potential to be effective inhibitors of $E$. coli. Malaysian honey, namely Tualang and Gelam honey have high antibacterial potency of total and non-peroxide activities implying that peroxide and other constituents are mutually important as contributing factors to the antibacterial system of honey. The correlations between MIC, MBC and osmatic and total acidity values of Malaysian honey were proven to be dependent on honey origin. TH honey showed the highest antibacterial activity, followed by $\mathrm{GH}$ and $\mathrm{AH}$ ones.
Differential gene expression in response to honey exposure exhibited downregulation of several genes involved in biofilm formation, quorum sensing, and stress survival in E. coli. The obtained results demonstrate that the honeys under study may represent promising antibacterial and anti-virulence agents for treatment and modulation of infections caused by $E$. coli. Future clinical evidence pertaining to the efficacy of the tested honeys in the prevention and treatment of $E$. coli-induced infections at various tissue/cell types might be required.

\section{Acknowledgments}

The authors would like to thank staff laboratory members of the Faculty of Health, (UniSZA) for their support. 


\section{Declaration of Competing Interest}

The authors declare that there is no competing interests.

\section{References}

1. Pećanac M, Janjić $Z$, Komarčević A, Pajić M, Dobanovački D, Mišković-Skeledžija S. Burns treatment in ancient times. Medicinski pregled 2013;66(5-6):263-7.

2. Majtán J. Apitherapy--the role of honey in the chronic wound healing process. Epidemiologie, mikrobiologie, imunologie: casopis Spolecnosti pro epidemiologii a mikrobiologii Ceske lekarske spolecnosti JE Purkyne 2009;58(3):137-40.

3. Vandamme L, Heyneman A, Hoeksema H, Verbelen J, Monstrey S. Honey in modern wound care: a systematic review. Burns 2013;39(8):1514-25.

4. Lotfy M, Badra G, Burham W, Alenzi F. Combined use of honey, bee propolis and myrrh in healing a deep, infected wound in a patient with diabetes mellitus. British JBS 2006;63(4):171-3.

5. Visavadia BG, Honeysett J, Danford MH. Manuka honey dressing: An effective treatment for chronic wound infections. Br J Oral Maxillofac Surg 2008;46(1):55-6.

6. Lusby PE, Coombes AL, Wilkinson JM. Bactericidal activity of different honeys against pathogenic bacteria. Arch Med Res 2005;36(5):464-7.

7. Mundo MA, Padilla-Zakour OI, Worobo RW. Growth inhibition of foodborne pathogens and food spoilage organisms by select raw honeys. Int J Food Microbiol 2004;97(1):1-8.

8. Wasfi R, Elkhatib WF, Khairalla AS. Effects of selected Egyptian honeys on the cellular ultrastructure and the gene expression profile of Escherichia coli. PloS one 2016;11(3).

9. Brudzynski K, Abubaker K, Castle A. Re-examining the role of hydrogen peroxide in bacteriostatic and bactericidal activities of honey. Front Microb 2011;2:213.

10. Mavric E, Wittmann S, Barth G, Henle T. Identification and quantification of methylglyoxal as the dominant antibacterial constituent of Manuka (Leptospermum scoparium) honeys from New Zealand Mol Nutr Food Res 2008;52(4):483-9.

11. Jenkins R, Burton N, Cooper R. Proteomic and genomic analysis of methicillin-resistant Staphylococcus aureus (MRSA) exposed to manuka honey in vitro demonstrated down-regulation of virulence markers. J Antimicrob Chemother 2014;69(3):603-15.

12. Blair $S, C$ arter $D$. The potential for honey in the management of wounds and infection. Aust Inf Cont 2005;10(1):24-31.

13. Abbas HA. Comparative antibacterial and antibiofilm activities of manuka honey and Egyptian clover honey. Asian J Appl Sci 2014;2(2).

14. Wang R, Starkey M, Hazan R, Rahme L. Honey's ability to counter bacterial infections arises from both bactericidal compounds and QS inhibition. Front Microb. 2012;3:144.
15. Elbanna K, Attalla K, Elbadry M, Abdeltawab A, Gamal-Eldin $H$, Ramadan MF. Impact of floral sources and processing on the antimicrobial activities of different unifloral honeys. Asian Pac J Trop Dise 2014;4(3):194-200.

16. Wasfi R, Elkhatib WF, Khairalla AS. Effects of selected Egyptian honeys on the cellular ultrastructure and the gene expression profile of Escherichia coli. PloS one 2016;11(3):e0150984.

17. Blair S, Cokcetin N, Harry E, Carter D. The unusual antibacterial activity of medical-grade Leptospermum honey: antibacterial spectrum, resistance and transcriptome analysis. Eur J Clin Microbiol Infect Dis 2009;28(10):1199-208.

18. Yadata D. Detection of the electrical conductivity and acidity of honey from different areas of Tepi. Food Science and Technology. 2014;2(5):59-63.

19. Belay A, Solomon W, Bultossa G, Adgaba N, Melaku S. Physicochemical properties of the Harenna forest honey, Bale, Ethiopia. Food Chem 2013;141(4):3386-92.

20. Al-kafaween MA, Hilmi ABM, Jaffar N, Al-Jamal HAN, Zahri MK, Jibril Fl. Antibacterial and Antibiofilm activities of Malaysian Trigona honey against Pseudomonas aeruginosa ATCC 10145 and Streptococcus pyogenes ATCC 19615. Jordan J Biol Sci 2020;13(1):69 - 76.

21. Al-kafaween MA, Hilmi ABM, Al-Jamal HAN, Elsahoryi NA, Jaffar N, Zahri MK. Pseudomonas Aeruginosa and Streptococcus Pyogenes Exposed to Malaysian Trigona Honey In Vitro Demonstrated Downregulation of Virulence Factor. Iran J Biotechnol 2020;18(4):115-23.

22. Zainol MI, Yusoff KM, Yusof MYM. Antibacterial activity of selected Malaysian honey. BMC 2013;13(1):1-10.

23. Mohammad AK, Hamid NJ, Abu Bakar MH, Nour AE, Norzawani J, Mohd KZ. Antibacterial properties of selected Malaysian Tualang honey against Pseudomonas aeruginosa and Streptococcus pyogenes. Iran J Microbiol 2020;12(6):565-76.

24. Henriques A, Jenkins R, Burton N, Cooper R. The intracellular effects of manuka honey on Staphylococcus aureus. Eur J Clin Microbiol Infect Dis 2010;29(1):45.

25. Pfaffl MW, Tichopad A, Prgomet C, Neuvians TP. Determination of stable housekeeping genes, differentially regulated target genes and sample integrity: BestKeeper-Excel-based tool using pair-wise correlations. Biotech J 2004;26(6):509-15.

26. Wu H, Wang H, Chen J, Chen G-Q. Effects of cascaded vgb promoters on poly (hydroxybutyrate) (PHB) synthesis by recombinant Escherichia coli grown micro-aerobically. Appl Microbiol Biotechnol 2014;98(24):10013-21.

27. Mandal MD, Mandal S. Honey: its medicinal property and antibacterial activity. Asian Pac J Trop Biomed. 2011;1(2):15460.

28. Al Kafaween MA, Hilmi ABM, Khan RS, Bouacha M, Amonov M. Effect of Trigona honey on Escherichia coli cell culture growth: In vitro study. J Apither 2019;5(2):10-7. 
29. Boorn K, Khor YY, Sweetman E, Tan F, Heard T, Hammer K. Antimicrobial activity of honey from the stingless bee Trigona carbonaria determined by agar diffusion, agar dilution, broth microdilution and time区kill methodology. J. Appl. Microbiol. 2010;108(5):1534-43.

30. Tan HT, Rahman RA, Gan SH, Halim AS, Asma'Hassan S, Sulaiman SA, et al. The antibacterial properties of Malaysian tualang honey against wound and enteric microorganisms in comparison to manuka honey. BMC. 2009;9(1):34.

31. Fatima I, AB MH, Salwani I, Lavaniya M. Physicochemical characteristics of malaysian stingless bee honey from trigona species. IIUM 2018;17(1).

32. Zulkhairi Amin FA, Sabri S, Mohammad SM, Ismail M, Chan KW, Ismail $\mathrm{N}$, et al. Therapeutic properties of stingless bee honey in comparison with european bee honey. Adv Pharmacol Sci 2018;2018.

33. Fuad A, Anwar N, Zakaria A, Shahidan N, Zakaria Z. Physicochemical characteristics of Malaysian honeys influenced by storage time and temperature. J Fundam Appl Sci 2017;9(2S):841-51.

34. Badawy O, Shafii S, Tharwat E, Kamal A. Antibacterial activity of bee honey and its therapeutic usefulness against Escherichia coli 0157: H7 and Salmonella typhimurium infection. Revue scientifique et technique (International Office of Epizootics) 2004;23(3):1011.

35. Irish J, Blair S, Carter DA. The antibacterial activity of honey derived from Australian flora. PloS one. 2011;6(3):e18229.

36. Anklam E. A review of the analytical methods to determine the geographical and botanical origin of honey. Food chem 1998;63(4):549-62.

37. Uhlich GA, Gunther NW, Bayles DO, Mosier DA. The CsgA and Lpp proteins of an Escherichia coli O157: H7 strain affect HEp2 cell invasion, motility, and biofilm formation. Infect Immun 2009;77(4):1543-52.
38. Weber MM, French $C L$, Barnes MB, Siegele DA, McLean RJ. A previously uncharacterized gene, yjfO (bsmA), influences Escherichia coli biofilm formation and stress response. Microbios 2010;156(Pt 1):139.

39. Zhang X-S, García-Contreras R, Wood TK. YcfR (BhsA) influences Escherichia coli biofilm formation through stress response and surface hydrophobicity. J Bacteriol 2007;189(8):3051-62.

40. Anthimidou E. actividad Mossialos D. antibacteriana de mieles griegas y chipriotas contra Staphylococcus aureus y Pseudomonas aeruginosa, en comparación con la miel de manuka. J Med Food 2013;16(1):42-7.

41. Lee J-H, Park J-H, Kim J-A, Neupane GP, Cho MH, Lee C-S, et al. Low concentrations of honey reduce biofilm formation, quorum sensing, and virulence in Escherichia coli 0157: H7. Biofouling 2011;27(10):1095-104.

42. Dong T, Schellhorn HE. Global effect of RpoS on gene expression in pathogenic Escherichia coli 0157: H7 strain EDL933. BMC 2009;10(1):349.

43. Nishino K, Yamaguchi A. EvgA of the two-component signal transduction system modulates production of the yhiUV multidrug transporter in Escherichia coli. J Bacteriol 2002;184(8):2319-23.

44. White-Ziegler CA, Davis TR. Genome-wide identification of $\mathrm{H}$-NS-controlled, temperature-regulated genes in Escherichia coli K-12. J Bacteriol 2009;191(3):1106-10.

\section{Publish in The International}

Arabic Journal of Antimicrobial Agents

The Journal is an open access peer-reviewed journal that publishes scientific papers about all aspects of antimicrobials. The journal will publish original research articles, reviews, brief reports and case reports dealing with basic and clinical antibacterial agents, antiviral, antiprotozoals, antituberculuous, antifungal and antihelminthes agents. All manuscripts must be prepared in English, and are subject to a rigorous and fair peer-review process. Accepted papers will immediately appear online. The journal aims to advance the knowledge, attitude and the research of chemotherapy in the Arabic world in cooperation with international, national scientific and public societies as well as research centers with similar aims and objectives. 